\title{
Pengaruh Persepsi Aparatur Sipil Negara Sekretaris Daerah Kabupaten Bandung Barat terhadap Minat Membayar Zakat Profesi
}

\author{
Shofya Humaira Siti Salma* \\ Prodi Hukum Ekonomi Syariah, Fakultas Syariah, Universitas Islam \\ Bandung, Indonesia. \\ *shofyahss@gmail.com
}

\begin{abstract}
Professional zakat is zakat issued by a person because he gets income or income that is cultivated through his expertise. The potential for professional zakat in West Java is estimated at IDR 21.88 trillion and in West Bandung Regency itself the potential for professional zakat can reach IDR 8 billion per year, but its realization is still low due to various obstacles in its collection. On that basis, the West Bandung Regent issued a government instruction to optimize professional zakat, especially from the State Civil Apparatus. Based on this phenomenon, this study aims to determine how the influence of ASN's perception of professional zakat and government instructions on interest in paying professional zakat. Researchers used quantitative methods with a descriptive approach. The research sample was $90 \mathrm{ASN}$ in the Regional Secretary of West Bandung which was obtained based on the Simple Random Sampling technique. Data collection techniques using questionnaires, interviews, and literature study. The analytical method used is multiple linear regression analysis and the hypothesis is tested using the $\mathrm{f}$ test and $\mathrm{t}$ test. The results of this study indicate that ASN's perception of professional zakat and ASN's perception of government instructions on interest in paying professional zakat are in high criteria and together have a positive and significant influence and the rest is influenced by other variables not discussed in this study.
\end{abstract}

Keywords: Professional Zakat, Government Instructions, Interest in Zakat.

Abstrak. Zakat profesi merupakan zakat yang dikeluarkan seseorang karena mendapatkan penghasilan atau pendapatan yang diusahakan melalui keahliannya. Potensi zakat profesi di Jawa Barat diperkirakan mencapai Rp 21,88 triliun dan di Kabupaten Bandung Barat sendiri potensi zakat profesi dapat mencapai $\mathrm{Rp} 8$ miliar pertahun, namun realisasinya masih rendah karena berbagai kendala dalam penghimpunannya. Atas dasar itu, Bupati Bandung Barat mengeluarkan instruksi pemerintah untuk mengoptimalkan zakat profesi khususnya dari kalangan Aparatur Sipil Negara. Berdasarkan fenomena tersebut, maka penelitian ini bertujuan untuk mengetahui bagaimana pengaruh persepsi ASN tentang zakat profesi dan instruksi pemerintah terhadap minat membayar zakat profesi. Peneliti menggunakan metode kuantitatif dengan pendekatan deskriptif. Sampel penelitian sebanyak 90 ASN di Sekretaris Daerah Bandung Barat yang didapatkan berdasarkan teknik Simple Random Sampling. Teknik pengumpulan datanya menggunakan kuesioner, wawancara, dan studi pustaka. Metode analisis yang digunakan adalah analisis regresi linear berganda dan hipotesis yang diuji menggunakan uji f dan uji t. Hasil penelitian ini menunjukkan bahwa persepsi ASN tentang zakat profesi dan persepsi ASN tentang instruksi pemerintah terhadap minat membayar zakat profesi berada pada kriteria tinggi dan secara bersama sama memiliki pengaruh yang positif dan signifikan dan sisanya dipengaruhi oleh variabel lain yang tidak dibahas dalam penelitian ini.

Kata Kunci: Zakat Profesi, Instruksi Pemerintah, Minat Membayar Zakat. 


\section{A. Pendahuluan}

Zakat merupakan kewajiban moneter dan kewajiban agama yang dikenakan kepada umat Islam yang memiliki kekayaan atau kelebiha harta berhak atas pembayaran zakat sesuai dengan prinsip Syari'ah (1). Secara garis besar zakat dibedakan menjadi dua, yaitu zakat nafs (zakat fitrah) dan zakat mal (zakat harta). Salah satu yang termasuk ke dalam zakat mal adalah zakat profesi.

Zakat profesi adalah zakat yang dikeluarkan karena memperoleh penghasilan atau pendapatan melalui keahlian seseorang atau yang umumnya dikenakan pada setiap pekerjaan, baik dilakukan sendiri atau dengan kelompok dari orang tertentu atau entitas yang menghasilkan uang zakat. Dalam istilah fiqh dikenal dengan nama al-mal al-mustafad (2).

Di era kontemporer dalam pandangan kalangan ulama zakat profesi memiliki dukungan dan pengaruh yang kuat karena memiliki landasan hukum yaitu UU No. 23 Tahun 2011 pasal 4 poin $\mathrm{h}$ tentang pengelolaan zakat pada pendapatan dan jasa, dimana dinyatakan oleh UU tersebut sebagai salah satu objek zakat mal di Indonesia (3). Selain itu, zakat profesi juga jauh sebelumnya telah diatur dalam fatwa MUI No. 3 Tahun 2003 tentang zakat profesi yang mewajibkan semua bentuk profesi yang halal wajib dikeluarkan zakatnya dengan syarat telah mencapai nisab dalam satu tahun yaitu senilai dengan harga emas 85 gram.

Namun kondisi zakat mal khususnya dari zakat profesi itu sendiri masih mengalami berbagai kendala dalam penghimpunannya. Di Jawa Barat sendiri potensi zakat penghasilan/zakat profesi mencapai Rp 21,88 triliun sedangkan saat ini yang terkumpul baru mencapai Rp 900 miliar, artinya masih jauh di bawah potensi yang ada. Bandung Barat merupakan salah satu kabupaten yang memiliki potensi besar dan signifikan dalam penghimpunan zakat profesi dari kalangan Aparatur Sipil Negara (ASN). Apabila ASN muslim berzakat setiap bulannya mengeluarkan zakat dengan nominal $\mathrm{Rp} 100.000$ per orang maka potensi zakat profesi yang terkumpul $\mathrm{Rp} 800 \mathrm{juta} / \mathrm{bulan}$ atau $\mathrm{Rp} 8 \mathrm{miliar} / \mathrm{tahun}$.

Akan tetapi, jika dilihat dari laporan penerimaan dana zakat profesi dari ASN di Pemerintah Daerah Bandung Barat di Badan Amil Zakat Kabupaten Bandung Barat pada emppat tahun terakhir, jumlah penghimpunannya hanya mencapai Rp 6,1 miliar dan angka tersebut masih jauh dari potensi zakat profesi Kabupaten Bandung Barat, hal ini dapat dilihat pada tabel berikut:

Tabel 1. Laporan Penerimaan Dana Zakat Profesi

\begin{tabular}{|c|c|}
\hline \multicolumn{2}{|c|}{ Penerimaan Dana Zakat Profesi } \\
\hline Tahun 2017 & Rp 614.964.000 \\
\hline Tahun 2018 & Rp 888.710.930 \\
\hline Tahun 2019 & Rp 2.067.808.330 \\
\hline Tahun 2020 & Rp 3.464.241.323 \\
\hline Jumlah 2017-2020 & Rp 6.154.164.556 \\
\hline
\end{tabular}

Sumber: BAZ Kabupaten Bandung Barat

Melihat hal tersebut, maka Bupati Bandung Barat mengeluarkna surat keputusan (SK) atau instruksi Bupati Nomor 400/1188/kesra tentang optimalisasi pengumpulan zakat di lingkungan pemerintah daerah Kabupaten Bandung Barat. Dengan adanya instruksi pemerintah pun, awalnya ASN ada yang setuju dan ada pula yang kurang setuju, karena jika zakat profesi dipotong langsung maka akan menjadi double taxation. Jika hal itu terjadi, maka tingkat minat berzakat para ASN tentu menjadi beragam dan dapat diprediksi bahwa persepsi ASN tentang zakat profesi ikut memengaruhi minat berzakat mereka.

Minat seseorang dalam berzakat berkaitan dengan tindakan untuk merealisasikan atau mencapai potensi zakat profesi. Salah satu faktor yang paling penting dalam mempengaruhi tindakan adalah minat, jika tidak ada minat, tidak ada yang terjadi (4). Perilaku seseorang untuk memunculkan minat terhadap zakat mungkin juga dipengaruhi oleh persepsi mereka tentang zakat profesi itu sendiri dan instruksi pemerintah. Karena jika persepsi ASN salah atau keliru, 
minat untuk berzakat dan penghimpunan dana zakat akan sulit untuk direalisasikan. Artinya, persepsi ini berfungsi sebagai dasar dalam memutuskan apakah ASN berminat untuk mengeluarkan zakat profesi atau tidak.

Berdasarkan latar belakang yang telah diuraikan, maka perumusan masalah dalam penelitian ini sebagai berikut: "Apakah terdapat pengaruh antara persepsi ASN terhadap minat membayar zakat profesi?". Selanjutnya, tujuan dalam penelitian ini diuraikan dalam pokokpokok sebagai berikut.

1. Untuk mengetahui persepsi ASN tentang zakat profesi dan instruksi pemerintah dalam membayar zakat profesi di Sekretaris Daerah Kabupaten Bandung Barat

2. Untuk mengetahui pengaruh persepsi ASN tentang zakat profesi terhadap minat membayar zakat profesi di Sekretaris Daerah Kabupaten Bandung Barat

3. Untuk mengetahui pengaruh persepsi ASN tentang instruksi pemerintah terhadap minat membayar zakat profesi di Sekretaris Daerah Kabupaten Bandung Barat

4. Untuk mengetahui pengaruh persepsi ASN secara simultan terhadap minat membayar zakat profesi di Sekretaris Daerah Kabupaten Bandung Barat

\section{B. Metodologi Penelitian}

Penelitian ini menggabungkan metode kuantitatif dengan pendekatan deskriptif sebagai metode penelitiannya. Penelitian ini berbentuk penelitian lapangan, dengan data yang dikumpulkan dari lapangan berupa hasil kuisioner yang disebar kepada ASN di Sekretaris Daerah Bandung Barat, dengan jumlah populasi 112 orang dan teknik pengambilan sampel Simple Random Sampling yang menghasilkan 90 responden yang dihitung menggunakan rumus Slovin. Instrumen penelitian diukur menggunakan skala Likert 1-5 dan kuesioner bersifat tertutup.

Kuesioner, wawancara, dan studi literatur digunakan sebagai alat untuk mengumpulkan data dalam penelitian ini. Adapun teknik analisis data yang dilakukan adalah analisis regresi linier berganda, yang meliputi berbagai pengujian seperti uji instrumen penelitian, uji asumsi klasik, analisis regresi linier berganda, dan pengujian hipotesis (uji F simultan, uji T parsial, dan koefisien determinasi).

\section{Hasil Penelitian dan Pembahasan}

Tabel 2. Hasil Uji Validitas

\begin{tabular}{|c|c|c|c|}
\hline Item & Rtabel & rhitung & Keterangan \\
\hline $\mathrm{X}_{1.1}$ & 0,2072 & .625 & Valid \\
\hline $\mathrm{X}_{1} .2$ & 0,2072 & .819 & Valid \\
\hline $\mathrm{X}_{1.3}$ & 0,2072 & .783 & Valid \\
\hline $\mathrm{X}_{1.4}$ & 0,2072 & .741 & Valid \\
\hline $\mathrm{X}_{1} .5$ & 0,2072 & .764 & Valid \\
\hline $\mathrm{X}_{1} .6$ & 0,2072 & .796 & Valid \\
\hline $\mathrm{X}_{1} .7$ & 0,2072 & .849 & Valid \\
\hline $\mathrm{X}_{1} .8$ & 0,2072 & .718 & Valid \\
\hline $\mathrm{X}_{1} .9$ & 0,2072 & .625 & Valid \\
\hline $\mathrm{X}_{1} .10$ & 0,2072 & .819 & Valid \\
\hline $\mathrm{X}_{1} .11$ & 0,2072 & .783 & Valid \\
\hline & & & \\
\hline
\end{tabular}




\begin{tabular}{|c|c|c|c|}
\hline $\mathrm{X}_{1 .} 12$ & 0,2072 & .625 & Valid \\
\hline $\mathrm{X}_{2.1}$ & 0,2072 & .782 & Valid \\
\hline $\mathrm{X}_{2.2}$ & 0,2072 & .866 & Valid \\
\hline $\mathrm{X}_{2.3}$ & 0,2072 & .881 & Valid \\
\hline $\mathrm{X}_{2.4}$ & 0,2072 & .878 & Valid \\
\hline $\mathrm{X}_{2.5}$ & 0,2072 & .840 & Valid \\
\hline$X_{2} .6$ & 0,2072 & .904 & Valid \\
\hline $\mathrm{X}_{2.7}$ & 0,2072 & .859 & Valid \\
\hline $\mathrm{X}_{2.8}$ & 0,2072 & .795 & Valid \\
\hline $\mathrm{X}_{2.9}$ & 0,2072 & .880 & Valid \\
\hline$X_{2 .} 10$ & 0,2072 & .881 & Valid \\
\hline Y.1 & 0,2072 & .619 & Valid \\
\hline Y.2 & 0,2072 & .813 & Valid \\
\hline Y.3 & 0,2072 & .778 & Valid \\
\hline Y.4 & 0,2072 & .870 & Valid \\
\hline Y.5 & 0,2072 & .741 & Valid \\
\hline Y.6 & 0,2072 & .768 & Valid \\
\hline Y.7 & 0,2072 & .813 & Valid \\
\hline Y.8 & 0,2072 & .856 & Valid \\
\hline Y.9 & 0,2072 & .733 & Valid \\
\hline Y.10 & 0,2072 & .619 & Valid \\
\hline Y.11 & 0,2072 & .718 & Valid \\
\hline Y.12 & 0,2072 & .751 & Valid \\
\hline Y.13 & 0,2072 & .804 & Valid \\
\hline
\end{tabular}

Berdasarkan Berdasarkan hasil perhitungan pada setiap butir pertanyaan yang diajukan memenuhi kriteria validitas, hal ini dapat dilihat dari hasil $r$ hitung lebih besar dari $r$ tabel 0,2072. Maka dapat disimpulkan bahwa seluruh item variabel hukum zakat profesi $\left(\mathrm{X}_{1}\right)$, intstruksi pemerintah $\left(\mathrm{X}_{2}\right)$ dan minat membayar zakat profesi $(\mathrm{Y})$ dinyatakan valid. 
Tabel 3. Hasil Uji Reliabelitas

\begin{tabular}{|c|c|c|c|}
\hline Variabel & Cronbach's Alpha & Standar & Keterangan \\
\hline Zakat profesi $\left(\mathrm{X}_{1}\right)$ & 0,929 & 0,60 & Reliabel \\
\hline Instruksi pemerintah $\left(\mathrm{X}_{2}\right)$ & 0,959 & 0,60 & Reliabel \\
\hline Minat (Y) & 0,933 & 0,60 & Reliabel \\
\hline
\end{tabular}

Berdasarkan hasil uji reliabilitas pada tabel 4.4 indikator variabel zakat profesi $\left(\mathrm{X}_{1}\right)$, instruksi pemerintah $\left(\mathrm{X}_{2}\right)$, dan minat membayar zakat profesi (Y) menghasilkan nilai Cronbach's Alpha yaitu di atas 0,60 merujuk pada tabel tingkat reliabilitas maka termasuk kategori reliabel, hal ini menunjukkan bahwa setiap indikator pertanyaan variabel datanya memberikan ukuran yang konsisten.

\section{Persepsi ASN tentang Zakat Profesi dan Instruksi Pemerintah Terhadap Minat Membayar Zakat Profesi di Sekretaris Daerah Kabupaten Bandung Barat}

Dengan adanya instruksi pemerintah dapat memberikan dorongan bagi ASN untuk membayar zakat profesi setiap bulannya, meskipun sebagian dari responden merasa terpaksa untuk membayarnya dan ada pula yang setuju dengan adanya pemotongan secara langsung dari gaji ASN. Hasil skor jawaban responden dalam kuesioner, instruksi pemerintah termasuk kriteria cukup tinggi.

ASN dalam melakukan pembayaran zakat profesi sudah cukup baik, hal inimenunjukkan bahwa ASN sadar akan manfaat dari zakat profesi untuk membantu kaum fakir miskin dan orang yang termasuk ke dalam 8 golongan mustahik, sadar bahwa membayar zakat profesi harus tepat waktu ketika sudah nishab, namun ASN menyatakan masih ragu hasil dari zakat profesi yang sudah dibayarkan digunakan untuk membentuk perencanaan yang baik untuk kesejahteraan rakyat.

Pengaruh Persepsi ASN tentang zakat profesi terhadap minat membayar zakat profesi

\section{Tabel 4. Hasil Uji T}

\begin{tabular}{|c|c|c|c|c|c|c|}
\hline \multicolumn{7}{|c|}{ Coefficients $^{a}$} \\
\hline \multirow{2}{*}{\multicolumn{2}{|c|}{ Model }} & \multicolumn{2}{|c|}{$\begin{array}{l}\text { Unstandardized } \\
\text { Coefficients }\end{array}$} & \multirow{2}{*}{$\begin{array}{c}\begin{array}{c}\text { Standardized } \\
\text { Coefficients }\end{array} \\
\text { Beta }\end{array}$} & \multirow[b]{2}{*}{$\mathrm{T}$} & \multirow{3}{*}{$\frac{\text { Sig. }}{0.001}$} \\
\hline & & B & Std. Error & & & \\
\hline & (Constant) & 22,692 & 6,347 & & 3,575 & \\
\hline & z.profesi & 0,265 & 0,131 & 0,197 & 2,014 & 0,047 \\
\hline
\end{tabular}

Berdasarkan hasil penelitian ini menunjukkan bahwa persepsi ASN tentang zakat profesi berpengaruh signifikan terhadap minat membayar zakat profesi. Dapat dilihat bahwa $\mathrm{T}_{\text {hitung }}$ untuk variabel zakat profesi sebesar 2,014 terdapat pengaruh persepsi ASN terhadap minat membayar zakat profesi (Y) sebesar 1,6626 hal ini berati $\mathrm{T}_{\text {hitung }} 2,014>\mathrm{T}_{\text {tabel }} 1,6626$. Artinya sebagian dari ASN itu menganggap bahwa zakat profesi itu menjadi wajib untuk dikeluarkan bagi yang sudah mencapai nishab walaupun memang menurut ASN bahwa zakat profesi itu merupakan produk hukum baru di era modern ini. 
Pengaruh Persepsi ASN tentang instruksi pemerintah terhadap minat membayar zakat profesi

Tabel 5. Hasil Uji T

\begin{tabular}{|c|c|c|c|c|c|c|}
\hline \multicolumn{7}{|c|}{ Coefficients $^{a}$} \\
\hline \multirow{2}{*}{\multicolumn{2}{|c|}{ Model }} & \multicolumn{2}{|c|}{$\begin{array}{l}\text { Unstandardized } \\
\text { Coefficients }\end{array}$} & \multirow{2}{*}{$\begin{array}{c}\begin{array}{c}\text { Standardized } \\
\text { Coefficients }\end{array} \\
\text { Beta } \\
\end{array}$} & \multirow{3}{*}{$\frac{T}{3,575}$} & \multirow{3}{*}{$\frac{\text { Sig. }}{0,001}$} \\
\hline & & B & $\begin{array}{l}\text { Std. } \\
\text { Error }\end{array}$ & & & \\
\hline & (Constant) & 22,692 & 6,347 & & & \\
\hline & Instruksi & 0,3750 & 0,102 & 0,359 & 3,675 & 0,000 \\
\hline
\end{tabular}

Berdasarkan tabel 5 di atas dapat dinyatakan bahwa secara parsial instruksi pemerintah adanya pengaruh positif signifikan terhadap minat membayar zakat profesi. Hal ini dibuktikan dari besaran $\mathrm{t}_{\text {hitung }} 3,675>\mathrm{t}_{\text {tabel }} 1,6626$, selain itu merujuk kepada tingkat signifikansi dapat dilihat dari hasil perhitungan uji $\mathrm{T}$ instruksi pemerintah didapatkan nilai signifikan $0,000<0,05$. Melihat dari analisis koefisien determinasinya instruksi pemerintah mempengaruhi minat ASN dalam membayar zakat profesi sebesar $34,8 \%$ artinya ASN menyatakan instruksi pemerintah dapat meningkatkan minat membayar zakat profesi.

\section{Pengaruh Persepsi ASN Secara Simultan Terhadap Minat Membayar Zakat Profesi di Sekretaris Daerah Kabupaten Bandung Barat}

Tabel 6. Hasil Uji F

\begin{tabular}{|c|c|c|c|c|c|c|}
\hline \multicolumn{7}{|c|}{ ANOVA $^{\mathrm{a}}$} \\
\hline \multicolumn{2}{|c|}{ Model } & Sum of Squares & Df & Mean Square & $\mathrm{F}$ & Sig. \\
\hline \multirow[t]{3}{*}{1} & Regression & 1513,927 & 2 & 756,963 & 10,315 &, $000^{\mathrm{b}}$ \\
\hline & Residual & 6384,695 & 87 & 73,387 & & \\
\hline & Total & 7898,622 & 89 & & & \\
\hline
\end{tabular}

Berdasarkan tabel 6 di atas dapat dinyatakan bahwa, nilai df1 sebesar 2 dan $\mathrm{df}_{2}$ sebesar 87, kemudian $\mathrm{F}_{\text {hitung }}$ lebih besar dari $\mathrm{F}_{\text {tabel }}$ yaitu 10,315 > 3,10 dan nilai signifikansi sebesar 0,000 < 0,05 . Sehingga dapat disimpulkan bahwa terdapat pengaruh positif signifikan antara variabel independen (persepsi tentang zakat profesi dan instruksi pemerintah) terhadap variabel dependen yaitu minat membayar zakat profesi.

Hal ini berarti dengan adanya persepsi yang baik tentang zakat profesi dan instruksi pemerintah, maka akan semakin tinggi tingkat minat dalam membayar zakat profesi

Tabel 7. Hasil Analisis Regresi Berganda

\begin{tabular}{|c|c|c|c|c|c|c|}
\hline \multicolumn{7}{|c|}{ Coefficients $^{a}$} \\
\hline \multirow{2}{*}{\multicolumn{2}{|c|}{ Model }} & \multicolumn{2}{|c|}{$\begin{array}{l}\text { Unstandardized } \\
\text { Coefficients }\end{array}$} & \multirow{2}{*}{$\begin{array}{c}\text { Standardized } \\
\text { Coefficients } \\
\text { Beta }\end{array}$} & \multirow[b]{2}{*}{$\mathrm{T}$} & \multirow[b]{2}{*}{ Sig. } \\
\hline & & B & Std. Error & & & \\
\hline \multirow[t]{2}{*}{1} & (Constant) & 22,692 & 6,347 & & 3,575 & 0,001 \\
\hline & z.profesi & 0,265 & 0,131 & 0,197 & 2,014 & 0,047 \\
\hline
\end{tabular}

JRES is licensed under Creative Commons Attribution-

NonCommercial-ShareAlike 4.0 International License. 


\begin{tabular}{|l|l|r|r|r|r|r|}
\hline & Instruksi & 0,375 & 0,102 & 0,359 & 3,675 & 0,000 \\
\hline
\end{tabular}

Berdasarkan tabel 7 di atas dapat dinyatakan bahwa, nilai konstanta (a) sebesar 24,930 mengindikasikan bahwa jika variabel dependen yaitu Minat Membayar Zakat Profesi adalah nol maka Minat Membayar Zakat Profesi adalah sebesar konstanta 24,930 \%. Nilai koefisien Persepsi ASN tentang Zakat Profesi $\left(\mathrm{X}_{1}\right)$ sebesar 0,265 maka mengindikasikan bahwa peningkatan Persepsi ASN tentang Zakat Profesi dalam satu satuan angka akan mengakibatkan kenaikan Minat Membayar Zakat Profesi sebesar 0,265\% dengan asumsi variabel lain konstan.

Nilai koefisien Persepsi ASN tentang Instruksi Pemerintah $\left(\mathrm{X}_{2}\right)$ sebesar 0,375 maka mengindikasikan bahwa peningkatan Persepsi ASN tentang Instruksi Pemerintah dalam satu satuan angka akan mengakibatkan kenaikan Minat Membayar Zakat Profesi sebesar 0,375\% dengan asumsi variabel lain konstan. Standar eror yang diperoleh sebesar 6,347. Maka dapat disimpulkan dari hasil perhitungan regresi linier berganda bahwa persepsi tentang zakat profesi $\left(\mathrm{X}_{1}\right)$ dan instruksi pemerintah $\left(\mathrm{X}_{2}\right)$ memiliki pengaruh positif terhadap minat membayar zakat profesi (Y).

Dari hasil regresi linier berganda pada tabel di atas maka dapat didapatkan bentuk persamaan regresinya menggunakan rumus:

$$
\begin{aligned}
& \mathrm{Y}=\alpha+\mathrm{b} 1 \mathrm{X} 1+\mathrm{b} 2 \mathrm{X} 2+\mathrm{e} \\
& \mathrm{Y}=22,692+0,265 \mathrm{X} 1+0,375 \mathrm{X} 2+6,347 \\
& \text { Keterangan: } \\
& \mathrm{Y} \quad=\text { Minat Membayar Zakat Profesi } \\
& \alpha \quad=\text { Konstanta } \\
& \mathrm{X} 1 \quad=\text { Persepsi ASN tentang Zakat Profesi } \\
& \mathrm{X} 2 \quad=\text { Persepsi ASN tentang Instruksi Pemerintah } \\
& \mathrm{e} \quad=\text { Error term }
\end{aligned}
$$

Tabel 8. Hasil Koefisien Determinasi

\begin{tabular}{|l|c|c|c|c|r|}
\hline \multicolumn{7}{|c|}{ Model Summary $^{\mathbf{b}}$} \\
\hline Model & $\mathrm{R}$ & $\mathrm{R}$ Square & $\begin{array}{c}\text { Adjusted R } \\
\text { Square }\end{array}$ & $\begin{array}{c}\text { Std. Error of the } \\
\text { Estimate }\end{array}$ & Durbin-Watson \\
\hline 1 &, $438^{\mathrm{a}}$ & 0,192 & 0,173 & 8,56664 & 2,063 \\
\hline \multicolumn{2}{|l|}{ a. Predictors: (Constant), instruksi, z.profesi } \\
\hline \multicolumn{2}{|l|}{ b. Dependent Variable: minat }
\end{tabular}

Koefisien determinasi digunakan untuk menentukan atau mengukur seberapa baik model dapat menjelaskan variabel terikat. Besarnya Adjusted R Square sebesar 0,192 yang berarti variabel $X_{1}$ dan $X_{2}$ memberikan kontribusi sebesar 19,2 persen, sedangkan sisanya sebesar 80,8 persen $(100-19,2)$ ditentukan oleh faktor lain, sesuai dengan tampilan hasil SPSS pada tabel $8 \mathrm{di}$ atas.

\section{Kesimpulan}

Berdasarkan pembahasan dalam penelitian ini, peneliti menyimpulkan beberapa hasil penelitian sebagai berikut:

1. Persepsi ASN tentang zakat profesi dan instruksi pemerintah dalam membayar zakat profesi di Sekretaris Daerah Kabupaten Bandung Barat termasuk ke dalam kriteria yang tinggi yaitu sebesar $60 \%$ artinya menunjukkan persepsi yang baik terhadap hukum zakat profesi, persepsi ASN terhadap instruksi pemerintah termasuk kriteria cukup tinggi yaitu sebesar 36\% menunjukkan persepsi yang baik artinya ASN mendukung atas pemotongan gaji untuk zakat profesi, dan persepsi ASN terhadap minat membayar zakat profesi termasuk kriteria tinggi yaitu sebesar 50\%.

2. Pengaruh persepsi ASN tentang zakat profesi terhadap minat membayar zakat profesi di Sekretaris Daerah Kabupaten Bandung Barat berdasarkan uji T secara parsial memiliki pengaruh yang positif dan signifikan sebesar $0,047<0,05$.

3. Pengaruh persepsi ASN tentang instruksi pemerintah terhadap minat membayar zakat 
profesi di Sekretaris Daerah Kabupaten Bandung Barat berdasarkan uji T secara parsial terdapat pengaruh yang positif dan signifikan sebesar $0,000<0,05$.

4. Pengaruh persepsi ASN secara simultan terhadap minat membayar zakat profesi di Sekretaris Daerah Kabupaten Bandung Barat berdasarkan uji $\mathrm{F}$ diperoleh nilai signifikansi sebesar 0,000 $<0,05$ artinya bahwa persepsi Aparatur Sipil Negara tentang zakat profesi dan instruksi pemerintah secara bersama-sama berpengaruh positif dan signifikan terhadap terhadap minat membayar zakat profesi. Uji Koefisien Determinasi (R) diperoleh nilai Adjusted $\mathrm{R}$ square sebesar 0,192. Hal ini dapat diartikan bahwa kontribusi variabel X1 dan X2 berpengaruh terhadap variabel $\mathrm{Y}$ sebesar 19,2\% sedangkan $80,8 \%$ dipengaruhi oleh faktor-faktor lain yang tidak diteliti dalam penelitian ini.

\section{Acknowledge}

Penulis mengucapkan terima kasih kepada Allah Swt, orang tua dan orang-orang terdekat yang selalu support untuk bisa sampai titik ini serta terima kasih kepada kedua dosen pembimbing karena telah membimbing penulis dalam proses penyusunan penelitian ini hingga selesai.

\section{Daftar Pustaka}

[1] Sawmar AA, Mochammed MO. Governance of Formal Zakat Institution in Saudi Arabia, Issues and Challenges to Improving Zakat Prayers' Compliance. Int J Zakat. 2019;4(2):23.

[2] Faizah RY. Pelaksanaan dan Pengelolaan Zakat Profesi dalam Tinjauan Fiqh dan PerundangUndangan di Indonesia. STAIN Salatiga; 2012.

[3] Umar MH, Zahidin. Pendekatan Hukum Zakat Profesi Menurut Ulama Konservatif dan Progresif. J Literasiologi. 2020;3(4):89.

[4] Amalia AN. Minat Masyarakat Jakarta Dalam Berwakaf Uang pada Lembaga Wakaf. J Ekon Islam Keuang dan Perbank. 2018;2(2):3. 